\title{
URGENSI PENDIDIKAN ANAK DALAM KELUARGA PERSPEKTIF ISLAM
}

\author{
Nanang Budianto \\ Fakultas Tarbiyah, IAI Al - Falah As - sunniyyah Kencong \\ ujungkulonpanembahan@gmail.com
}

\begin{abstract}
The first and the prime education for children in Islam is the Islamic family education. This family education is based upon Islamic guidance in purpose of building children's faith, piety, highest endeavor - including ethics, morality, and spirituality, and the practice of religious values in daily life. This effort is a kind of amar makruf nahi munkar in family scope. Children needs family model for their future mental and spiritual development. The model and methods of Islamic education in the family scopes are adopted pretty much from the way of our prophet Muhammad taught his family and his companions. Muslim believes that whatever done by the prophet is the manifestation of Quranic essence. In the implementation level, the prophet let his companions and his follower to develop the teaching as long as the development itself in line with educational principles by the prophet.
\end{abstract}

Keywords: Education, Islam, and Family.

\section{PENDAHULUAN}

Keluarga merupakan unit sosial terkecil yang utama dan pertama bagi seorang anak. Sebelum ia berkenalan dengan dunia sekitarnya, seorang anak akan berkenalan terlebih dahulu dengan situasi keluarga. Pengalaman pergaulan dalam keluarga akan memberikan pengaruh yang sangat besar bagi perkembangan anak untuk masa yang akan datang. Keluarga sebagai pendidikan yang pertama dan utama bagi anak. ${ }^{1}$ Orang tua merupakan pendidik utama dan pertama bagi anakanak mereka karena dari merekalah anak mulai menerima pendidikan. ${ }^{2}$ Pada setiap anak terdapat suatu dorongan dan daya untuk meniru. Dengan dorongan ini anak dapat mengerjakan sesuatu yang dikerjakan oleh orang tuanya. Oleh karena itu orang tua harus menjadi teladan bagi anak-anaknya. Apa saja yang didengarnya dan dilihat selalu ditirunya tanpa mempertimbangkan baik dan buruknya. Dalam hal ini sangat diharapkan kewaspadaan serta perhatian yang besar dari orang tua.

${ }^{1}$ Ahmad Tafsir, Ilmu Pendidikan dalam Perspektif Islam (Bandung: Remaja Rosda Karya, 2001), hal.155.

2 Armai Arief, Pengantar Ilmu dan Metodologi Pendidikan Islam (Jakarta: Ciputat Pers, 2002), hal. 76. 


\section{Nanang Budianto}

Karena masa meniru ini secara tidak langsung turut membentuk watak anak di kemudian hari.

Anak adalah generasi penerus bangsa. Anak dan masa depan adalah satu kesatuan yang dapat diwujudkan untuk membentuk suatu generasi yang dibutuhkan oleh bangsa terutama bangsa yang sedang membangun. Peningkatan keterampilan, pembinaan mental dan moral harus lebih ditingkatkan begitu juga dengan aspek-aspek lainnya. Menghadapi era globalisasi yang ditandai dengan berbagai perubahan tata nilai, maka anak harus mendapat pembinaan intensif dan terpadu. Untuk itu, orang tua harus memperhatikan perkembangan jasmani, ruhani, dan akal anak-anaknya. ${ }^{3}$ Pendidikan anak yang pertama dan paling utama dalam Islam adalah pendidikan dalam keluarga yang berperspektif Islam. Pendidikan dalam keluarga yang berperspektif Islam adalah pendidikan yang didasarkan pada tuntunan agama Islam yang diterapkan dalam keluarga yang dimaksudkan untuk membentuk anak agar menjadi manusia yang beriman dan bertaqwa pada Tuhan Yang Maha Esa, serta berakhlak mulia yang mencakup etika, moral, budi pekerti, spiritual atau pemahaman dan pengalaman nilai-nilai keagamaan dalam kehidupan sehari-hari. Yang nantinya hal itu merupakan sumbangan penting bagi pembangunan bangsa dan negara. Tanggung jawab besar orang tua untuk mendidik anak menjadi pribadi yang shaleh tertuang dalam firman Allah SWT surat al-Tahrim ayat 6, yang artrinya: "Hai orang-orang yang beriman, peliharalah dirimu dan keluargamu dari api neraka yang bahan bakarnya adalah manusia dan batu; penjaganya malaikat-malaikat yang kasar, keras, dan tidak mendurhakai Allah terhadap apa yang diperintahkan-Nya kepada mereka dan selalu mengerjakan apa yang diperintahkan."4

Dengan masyarakat yang mayoritas muslim dan pendidikan yang cukup beragam serta latar belakang budaya yang berbeda penulis bermaksud melakukan kajian mengenai pendidikan berperspektif Islam yang semestinya diterapkan oleh orang tua terhadap anak-anak dalam keluarga. Dengan merujuk pada latar belakang di atas maka rumusan masalah dalam kajian ini adalah: Bagaimanakah pendidikan anak berperspektif Islam yang diterapkan orang tua terhadap anak-anak dalam kehidupan di lingkungan keluarga?.

${ }^{3}$ Hery Noer Aly, Munzier, Watak Penidikan Islam (Jakarta: Friska Agung Insani, 2003), hal. 220.

${ }^{4}$ Departemen Agama RI, Al-Qwran dan Terjemahnya (Semarang: Kumudasmoro Grafindo, 1994).

46 | FaLASIFA, Vol. 10 Nomor 1 Maret 2019 


\section{PEMBAHASAN}

\section{Urgensi Keluarga}

Keluarga adalah suatu institusi yang terbentuk karena suatu ikatan perkawinan antara sepasang suami istri untuk hidup bersama seia sekata, seiring dan setujuan, dalam membina mahligai rumah tangga untuk mencapai keluarga sakinah dalam lindungan dan ridha Allah SWT. Keluarga merupakan lembaga pendidikan yang bersifat informal, yaitu pendidikan yang tidak mempunyai program yang jelas dan resmi, selain itu keluarga juga merupakan lembaga yang bersifat kodrati, karena terdapatnya hubungan darah antara pendidik dan anak didiknya. ${ }^{5}$ Di dalamnya selain ada ayah dan ibu juga ada anak yang menjadi tanggung jawab orang tua. Keluarga merupakan persekutuan hidup terkecil dari masyarakat yang luas.

Keluarga merupakan ladang terbaik dalam penyemaian nilainilai agama. Pendidikan dan penanaman nilai-nilai agama harus diberikan kepada anak sedini mungkin, salah satunya melalui keluarga sebagai tempat pendidikan pertama yang dikenal oleh anak. ${ }^{6}$ Menurut Zuhairini, pendidikan keluarga merupakan lembaga pendidikan pertama, tempat anak pertama kalinya menerima pendidikan dan bimbingan dari orang tua atau anggota keluarga lainnya. Di dalam keluarga inilah tempat meletakkan dasar-dasar kepribadian anak didik pada usia yang masih muda, karena pada usia ini anak lebih peka terhadap pengaruh dari pendidikan (orang tua dan anggota lain). ${ }^{7}$

Anak dalam menuju kedewasaannya memerlukan bermacam-macam proses yang diperankan oleh bapak dan ibu dalam lingkungan keluarga. Keluarga merupakan wadah yang pertama dan dasar bagi perkembangan dan pertumbuhan anak. Pengalaman empiris membuktikan bahwa institusi lain di luar keluarga tidak dapat menggantikan seluruhnya peran lembaga bahkan pada institusi non keluarga. Kesadaran orang tua akan peran dan tanggung jawabnya selaku pendidik pertama dan utama dalam keluarga sangat diperlukan. Tanggung jawab orang tua terhadap anak tampil dalam bentuk yang bermacam-macam. Dalam hal ini, orang tua adalah pendidik pertama dan utama dalam keluarga sesuai sabda Rasulullah SAW:

قال النبي صل الله عليه وسلم كل مولود يولد على الفطرة فأبواه يهودانه أو ينصرانه أو يمجسانه Artinya :

'Nabi Mubammad SAW bersabda: setiap bayi yang labir adalah fitrah maka kedua orang tuanya lah yang menjadikan ia Yahudi, Nashrani ataupun Ma-

\footnotetext{
${ }^{5}$ Suwarno, Pengantar Umum Pendidikan (Jakarta: Rineka Cipta, 1992), hal. 66.

${ }^{6}$ http://muslim.or.id.

${ }^{7}$ Zuhairini, dkk., Metodik Khusus Pendidikan Agama (Surabaya: Usaha Nasional, 1981), hal. 38.
} 
Nanang Budianto

jusi” (HR. Bukhari). ${ }^{8}$

\section{PengertianPendidikan Islam}

Ahli pendidikan Islam mengartikan pendidikan dengan mengambil tiga istilah, yaitu: Ta'lim, Ta'dib, dan Tarbiyah. Muhammad Athiyyah al-Abrasyi dalam bukunya Ruh al-Tarbiyah wa al-Ta'lim mengartikan Tarbiyah sebagai suatu upaya maksimal seseorang atau kelompok dalam mempersiapkan anak didik agar bisa hidup sempurna, bahagia, cinta tanah air, fisik yang kuat, akhlak yang sempurna, lurus dalam berpikir, berperasaan yang halus, terampil dalam bekerja, saling menolong dengan sesama, dapat menggunakan pikirannya dengan baik melalui lisan maupun tulisan, dan mampu hidup mandiri. ${ }^{9}$

Al-Attas sebagaimana dikutip Hasan langgulung menjelaskan bahwa Ta'lim hanya berarti pengajaran. Sedangkan kata Tarbiyah mempunyai makna yang terlalu luas karena kata Tarbiyah juga digunakan untuk binatang dan tumbuhtumbuhan dengan pengertian memelihara atau membela, menternak, dan lainlain. Kata Ta'dib menurut al-Attas lebih tepat mempunyai pengertian tidak sekedar pengajaran dan hanya untuk manusia. Selain itu kata Ta'dib itu erat hubungannya dengan kondisi ilmu dan Islam yang termasuk dalam sisi pendidikan. ${ }^{10}$

Dari beberapa pengertian di atas, pada intinya yang dimaksud pendidikan ialah suatu usaha seseorang kepada orang lain dalam membimbing agar seseorang itu berkembang secara maksimal. Baik yang diselenggarakan oleh keluarga, sekolah dan masyarakat yang mencakup pembinaan aspek jasmani, ruhani, dan akal peserta didik. Pendidikan agama ialah pendidikan yang mencakup penanaman nilai-nilai keagamaan dengan ajaran agama dan kepercayaan masing-masing. Pendidikan agama harus ditanamkan pada anak sedini mungkin, bahkan saat anak masih dalam kandungan. Dalam pandangan Islam, manusia lahir dengan membawa fitrah keagamaan yang harus dikembangkan lebih optimal lagi, yaitu oleh orang tua sebagai pendidik pertama dan utama, agar menjadi manusia yang beriman dan bertakwa pada Tuhan-nya.

\section{Dasar Pendidikan Agama dalam Keluarga}

Masa depan kualitas kehidupan suatu generasi, terkait dan sangat dipengaruhi oleh suasana kehidupan keluarga masa kini. Mutu moral kehidupan yang te-

\footnotetext{
${ }^{8}$ http://hadith.al-Islam.com.

${ }^{9}$ M. 'Athiyah Al-Abrasyi, Dasar-dasar Pokok Pendidikan Islam. Terj. Bustami A. Gani dan Djohar Bahry (Jakarta: Bulan Bintang, 1970), hal. 14.

${ }^{10}$ Hasan Langgulung, Asas-Asas Pendidikan Islam (Jakarta: Pustaka al-Husna Baru,
} 2003), hal. 3.

48 | FaLASIFA, Vol. 10 Nomor 1 Maret 2019 
lah melembaga dalam suatu rumah tangga akan sangat memengaruhi moral anak turunannya (karakter anak-anaknya). Bila kualitas moral dan karakter suatu keluarga tinggi, akan tinggi pula peluang keberhasilan anak turunannya, demikian juga sebaliknya.

Keluarga merupakan pendidikan pertama dan yang utama bagi anak. Karena dalam keluargalah anak mengawali perkembangannya. Baik itu perkembangan jasmani maupun perkembangan ruhani. Peran keluarga dalam pendidikan bagi anak yang paling utama ialah dalam penanaman sikap dan nilai hidup, pengembangan bakat dan minat, serta pembinaan kepribadian. Adapun yang bertindak sebagai pendidik dalam pendidikan agama dalam keluarga ialah orang tua yaitu ayah dan ibu serta semua orang yang bertanggung jawab terhadap perkembangan anak itu seperti kakek, nenek, paman, bibi dan kakak. Namun yang paling utama ialah ayah dan ibu. ${ }^{11}$

Orang tua harus memerhatikan perkembangan jasmani, akal, dan ruhani anak-anaknya, dengan tujuan agar anak dapat berkembang secara maksimal. Perlu disadari pula bahwa anak dilahirkan dengan membawa bakat, potensi, kemampuan serta sikap dan sifat yang berbeda. Untuk itu orang tua sebagai pendidik dalam keluarga perlu memahami perkembangan jiwa anak, agar dapat menentukan metode yang sepatutnya diterapkan dalam mendidik dan membimbing anakanaknya. Orang tua harus bersikap lemah lembut serta tidak boleh memaksakan metode yang tidak sesuai dengan perkembangan jiwa anak.

Setiap anak adalah individu yang tidak dapat diibaratkan sebagai tanah liat yang bisa "dibentuk" sesuka hati oleh orang tua. Namun harus disesuaikan dengan perkembangan jiwa dan potensi anak sebagai tanda kasih sayang dan tanggung jawab moral orang tua yang secara konsisten dilandasi oleh sikap dipercaya dan mempunyai suatu pola relasi hubungan antara kesadaran kewajiban dengan kepatuhan terhadap orang tua atas kesadaran tersebut.

Pendidikan yang paling utama dalam keluarga ialah yang mencakup pendidikan ruhani anak atau pendidikan agama. Pendidikan agama dimaksudkan untuk meningkatkan potensi spiritual anak agar menjadi manusia yang beriman, bertaqwa pada Tuhan Yang Maha Esa dan berakhlak mulia. Menurut Ahmad Tafsir dalam bukunya Ilmu Pendidikan dalam Persfektif Islam, ada dua arah mengenai kegunaan pendidikan agama dalam keluarga. Pertama, penanaman nilai dalam arti pandangan hidup yang kelak mewarnai perkembangan jasmani akalnya. Kedua, penanaman sikap yang kelak menjadi basis dalam menghargai guru dan pengeta-

\footnotetext{
${ }^{11}$ Ali Abdul Halim Mahmud, Pendidikan Rubani (Jakarta: Gema Insani, 2000), hal.
} 46. 
Nanang Budianto

huan di sekolah. ${ }^{12}$

Memasuki era globalisasi yang ditandai dengan berbagai perubahan tata nilai, maka anak harus disiapkan sedini mungkin dari hal-hal yang dapat merusak mental dan moral anak, yaitu dengan dasar pendidikan agama dalam keluarga. Sehingga anak diharapkan mampu menyaring dan tangguh dalam menghadapi tantangan, hambatan, dan perubahan yang muncul dalam pergaulan di masyarakat.

Menurut al-Ghazali, anak adalah amanat dari Allah SWT dan harus dijaga dan dididik untuk mencapai keutamaan dalam hidup dan mendekatkan diri pada Allah SWT. Semua bayi yang dilahirkan ke dunia bagaikan sebuah mutiara yang belum diukur dan belum berbentuk tapi amat bernilai tinggi. Maka kedua orang tuanyalah yang akan mengukir dan membentuknya menjadi mutiara yang berkualitas tinggi dan disenangi semua orang. Dalam mendidik anak, tentunya harus ada kesepakatan antara bapak ibu sebagai orang tua, akan dibawa kepada pendidikan yang otoriter atau pendidikan yang demokratis atau bahkan yang liberal, sebab mereka penentu pelaksana dalam keluarga. Dalam kehidupan masyarakat terkecil, yaitu keluarga, suami secara fungsional adalah penanggung jawab utama rumah tangga (keluarga) sedangkan istri adalah mitra setia yang aktif konstruktif mengelola rumah tangga. Operasionalisasi kehidupan berkeluarga sebaiknya dilakukan berdasarkan amar makruf nahi munkar.

Salah satu wujud amar makruf nahi munkar dalam kehidupan berkeluarga adalah memberikan pendidikan kepada putra putrinya berdasarkan ajaran Islam. Antara keluarga satu dengan keluarga lainnya mempunyai prinsip dan sistem sendirisendiri dalam mendidik anaknya. Namun orang tua jangan terbuai atau melupakan terhadap ajaran-ajaran Islam, terutama dalam hal pendidikan anak sebagaimana yang telah dicontohkan Rasul SAW sebagai pembawa panji-panji Islam, Rasul SAW tidak pernah mendidik putra-putrinya dengan pendidikan keras dan tidak dengan membebaskan anak-anaknya, tetapi beliau dalam mendidik keluarganya terutama kepada anak-anaknya adalah dengan limpahan kasih sayang yang amat besar. Senada dengan yang dikatakan oleh sahabat Anas ra. yaitu "aku tidak mendapatkan seseorang yang kasih sayangnya pada keluarganya melebihi Rasulullah SAW.”

Dari uraian diatas jelaslah bahwa tanggung jawab orang tua terhadap anaknya sangatlah besar, terutama dalam pendidikannya. Pendidikan agama dalam keluarga telah disyariatkan oleh Allah SWT dalam al-Quran dan diinterpretasikan melalui hadits Nabi Muhammad SAW. Diantaranya adalah sebagai berikut:

\footnotetext{
${ }^{12}$ Ahmad Tafsir, Ilmu Pendidikan dalam Persfektif Islam, hal. 51.
} 
1. Al-Quran Surat At-Tahrim ayat 6, artinya ;

"Hai orang-orang yang beriman, peliharalah dirimu dan keluargamu dari api neraka yang bahan bakarnya adalah manusia dan batu; penjaganya malaikatmalaikat yang kasar, yang keras, yang tidak mendurhakai Allah terhadap apa yang diperintahkan-Nya kepada mereka dan selalu mengerjakan apa yang diperintahkan.”

2. Al-Quran Surat Al-Kahfi ayat 46, artinya;

"Harta dan anak-anak adalah perhiasan kehidupan dunia tetapi amalan-amalan yang kekal lagi shaleh adalah lebih baik pahalanya di sisi Tuhanmu serta lebih baik untuk menjadi harapan.”

3. Al-Quran Surat Al-Furqon ayat 74-75, artinya;

"Dan orang-orang yang berkata: Ya Tuhan kami, anugerahkanlah kepada kami istri-istri kami dan keturunan kami sebagai penyenang hati (kami), dan jadikanlah kami imam bagi orang-orang yang bertakwa. Mereka itulah orang yang dibalas dengan martabat yang tinggi (dalam surga) karena kesabaran mereka dan mereka disambut dengan penghormatan dan ucapan selamat di dalamnya."

4. Rasulullah SAW bersabda;

$$
\text { ما من مولود إلا يولد على الفطرة فأبواه يهودانه وينصرانه ويمجساناه }
$$

Artinya: "Semua anak dilabirkan membawa fitrah (bakat keagamaan), maka terserah kepada kedua orang tuanya untuk menjadikannya beragama Yahudi, atau Nasrani, atau Majusi” (HR. Muslim).

5. Rasulullah SAW bersabda, yang artinya;

"Kewajiban orang tua kepada anaknya ialah memberi nama yang baik, mendidik sopan santun dan mengajari tulis menulis, renang, memanah, memberi makan dengan makanan yang baik serta mengawinkannya apabila ia telah mencapai dewasa” (HR. Muslim).

6. Rasulullah SAW bersabda;

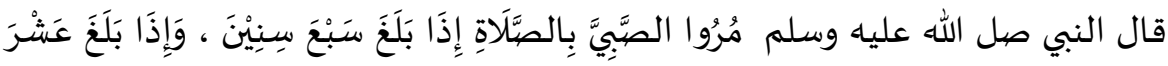

$$
\begin{aligned}
& \text { سِنِيْنَنَ فَاضْرِبْوُهُ عَلَيْنَة }
\end{aligned}
$$

Artinya: "Surublah anak-anakmu Shalat ketika berusia tujub tabun, dan pukulah mereka (jika tidak man) Shalat ketika sepuluh tahun, dan pisabkanlah tempat tidur mereka” (HR. Abu Dawnd).

Dari beberapa keterangan di atas, baik al-Quran maupun al Hadits mengisyaratkan bahwa pendidikan dalam keluarga itu sangat penting terutama dalam pendidikan agama. Pendidikan yang ditanamkan orang tua pada anak merupakan landasan dasar berpijak anak dalam berpikir dan berkembang secara jasmani, ru-

FaLASIFA, Vol. 10 Nomor 1 Maret 2019 | 51 
Nanang Budianto

hani dan mental anak.

Dalam pandangan Islam, pendidikan dimulai dalam keluarga jauh sebelum anak lahir, yaitu dengan terlebih dahulu memilih pasangan hidup. Calon ayah harus memilih calon ibu yang baik, begitupun sebaliknya. Karena ayah dan ibu akan berpengaruh besar terhadap perkembangan anak-anaknya. Ayah dan ibu yang tidak baik, tidak akan mampu mendidik anaknya untuk menjadi baik. Dalam hal ini, Rasulullah SAW memberikan kriteria sebagai berikut:

"Wanita dinikahi karena empat kriteria: Karena hartanya banyak, karena turunannya baik, karena rupanya baik, karena agamanya baik. Beruntunglah kamu yang memilih wanita karena agamanya, dengan demikian kamu akan berbahagia” (HR. Bukhori Muslim).

Kriteria penting menurut hadits di atas ialah beragama. Harta dan kecantikan suatu saat akan hilang, begitu pula dengan keturunan baik, tidak akan menjamin kebahagiaan. Bahkan dengan harta, kecantikan, dan keturunan baik mungkin akan membuat seseorang tinggi hati dan sombong. Dan yang menjamin kebahagiaan seseorang ialah apabila orang itu beragama, dan berpegang teguh pada ajaran agamanya. Itulah yang akan menyelamatkannya di dunia dan akhirat.

Pendidikan anak sebelum anak lahir sebenarnya dilakukan bukan terhadap anak itu, melainkan terhadap ayah dan ibunya yang secara tidak langsung akan mempengaruhi perkembangan anak, terutama saat proses kehamilan. Kedua belah pihak yaitu ayah dan ibu diharapkan hidup tenang, banyak berdoa dan beribadah pada Allah SWT agar diberi anak yang cerdas, luhur budi pekertinya dan rupawan. Wujud dari upaya ini secara individu adalah dengan banyak membaca al-Quran, menjaga lisan dan perbuatan. Selama masa kehamilan, orang tua terutama ibu berusaha untuk tidak mengolak-olok orang lain. Ini tercermin dalam pepatah jawa "Sing moyok bakal nemplok." Dalam sikap sehari-hari, pada masa kehamilan biasanya orang tua juga tidak berani membunuh binatang ataupun yang lainnya karena ada persepsi akan berpengaruh terhadap bayi yang lahir nantinya.

Sudah menjadi tradisi dalam kalangan sebagian muslim di jawa, pada saat kehamilan ada tradisi mapati, mitoni (atau disebut munari). Tradisi mapati yaitu selamatan baca Quran dan do'a bersama pada usia empat bulan kehamilan. Tujuan mapati adalah berdo'a kepada Allah SWT agar anak yang ada dalam kandungan nantinya menjadi anak yang sempurna secara fisik maupun ruhani. Secara fisik anak tersebut lengkap anggota tubuhnya dan sehat. Secara ruhani bayi nantinya menjadi anak shaleh/shalehah, mendapatkan umur panjang, dan rizki yang melimpah. Surat-surat al-Quran yang dibaca dalam tradisi mapati adalah Surat Yusuf,

52 | FaLASIFA, Vol. 10 Nomor 1 Maret 2019 
Surat Maryam, Surat Luqman, Surat Waqiah. ${ }^{13}$ Tradisi mapati ini didasari oleh hadis nabi yang manyatakan bahwa pada umur empat bulan Allah akan meniupkan ruh kepada sang janin lalu menetapkan umur, rezki, jodoh dan kematiannya.

Pada umur tujuh bulan kehamilan, orang tua melaksanakan tradisi mitoni (munari). Ini dilaksankan dengan tujuan bahwa janin yang sudah berumur tujuh bulan tersebut dido'akan agar sehat dan selamat sampai lahir. Tujuannya bukan hanya berdo'a untuk sang janin tetapi juga berharap semoga nanti dalam persalinan, sang ibu diberi kekuatan dan keselamatan sehingga proses persalinannya berjalan dengan lancar.

Setelah anak lahir, barulah pendidikan itu dilakukan secara langsung pada anak tersebut. Ada beberapa upaya dalam pandangan Islam yang semestinya dilakukan orang tua dalam pendidikan anak, diantaranya sebagai berikut :

a. Melakukan azan dan iqamah, azan di telinga kanan dan iqamah di telinga kiri.

Hal ini menurut Ibn al-Doyyin al-Jaujiyah dimaksudkan agar getaran-getaran pertama yang didengar oleh si anak adalah kalimat panggilan agung yang mengandung kebesaran Allah SWT dan kesaksian pertama masuk Islam.

b. Mencukur rambut pada saat bayi berusia 7 hari, dan melakukan Aqiqah, sebagai sunnah Rasulullah SAW.

c. Memberi nama yang baik.

Orang tua hendaknya memberikan nama yang baik bagi anak-anaknya. Nama dapat memengaruhi pergaulan anak. Nama yang baik akan menumbuhkan rasa percaya diri pada anak, dan sebaliknya nama yang buruk akan menjadikan anak minder, karena namanya menjadi bahan olok-olokan oleh temannya. Dalam tradisi masyarakat pemberian nama pada sang bayi biasanya disebut dengan walimah al-tasmiyah. Tradisi walimah al-tasmiyah ini ada yang dilaksanakan dengan mengundang sanak kerabat dan tetangga sekitar. Dalam tradisi ini biasanya dilaksanakan pembacaan shalawat nabi. Shalawat nabi yang dibaca biasanya adalah kitab al-barzanji.

${ }^{13}$ Dengan mambaca Surat Yusuf, orang tua berharap agar Allah memberikan anak yang rupawan sebagaimana ketampanan Nabi Yusuf as. Ini jika Allah menganugerahkan anak laki-laki. Dengan membaca Surat Maryam, orang tua berharap agar Allah menganugerahkan anak yang mempunyai kecantikan dhohir ban bathin sebagaimana Siti Maryam. Beliau adalah wanita yang teguh menjaga diri dan mampu bertahan dengan segala ujian Allah. Ini jika Allah memberikan anak perempuan. Melalui bacaan Surat Lukman, orang tua berharap agar Allah kelak menjadikan anaknya menjadi anak yang punya kebijakan dalam mendidik sebagaimana Luqman al-Hakim. Sedangkan dengan membaca surat waqi’ah, diharapkan nantinya anak dilimpahkan rizkinya oleh Allah SWT.

FALASIFA, Vol. 10 Nomor 1 Maret 2019 | 53 
Nanang Budianto

Pada saat pembacaan shalawat nabi, tepatnya pada saat berdiri (mahalul qiyam) sang bayi digendong oleh sang ayah. Bayi tersebut dibawa berkeliling dengan minyak wangi dihadapkan pada semua orang yang hadir di acara tersebut. Ini dimaksudkan meminta do'a kepada seluruh yang hadir supaya anak tersebut menjadi anak yang shaleh/shalehah.

d. Melakukan khitan Khitan

Sebagai salah satu ajaran Islam menjadi hal yang sangat diperhatikan oleh orang tua. Khitan ini berlaku bagi anak laki-laki maupun perempuan. Pelaksanaan khitan bagi anak lakilaki dilaksanakan pada anak berusia sekolah dasar. Sedangkan pelaksanaan khitan bagi anak perempuan biasanya dilaksanakan pada hari ke-40 dari kelahiran. Dalam istilah jawa anak perempuan sudah umur selapan.

Dalam acara khitan ini baik bagi anak laki-laki maupun perempuan diadakan acara selamatan atau do'a bersama kelurga dan tetangga sekitar. Pada saat khitan ini juga, terkadang orang tua baru melakukan Aqiqah bagi anak-anak mereka. Adapun kegunaan khitan dalam pendidikan anak antara lain :

1) Anak dilatih mengikuti ajaran Nabi;

2) Khitan membedakan pemeluk Islam dari pemeluk agama lain;

3) Khitan merupakan pengakuan penghambaan manusia terhadap Tuhan;

4) Khitan membersihkan badan, berguna bagi kesehatan, memperkuat syahwat.

5) Menyusui bayi

Menyusui bayi mempunyai dampak positif terhadap perkembangan anak, baik fisik maupun mental. Dari segi perkembangan fisik, susu ibu lebih baik daripada susu buatan atau hewan. Pada saat ibu menyusui anaknya, sebenarnya ia sedang mencurahkan kasih sayangnya kepada anak dan akan dirasakan sebagai suatu kehangatan kasih ibu yang melindungi. Ini besar pengaruhnya terhadap perkembangan jiwa anak. Apalagi ketika dalam posisi menyusui, ibu sambil mendengungkan, melantunkan shalawat ditelinga sang bayi. Maka akan tertanam rasa cinta anak terhadap rasulnya.

\section{Pola Pendidikan Anak dalam Keluarga Perspektif Islam}

Pendidikan anak menurut pandangan Islam yang harus dilakukan dalam keluarga adalah dengan menggunakan beberapa pola pendidikan. Pola atau dapat disebut juga sebagai metode merupakan suatu cara yang dilakukan oleh pendidik dalam menyampaikan nilai-nilai atau materi pendidikan pada peserta didik untuk mencapai tujuan pendidikan itu sendiri sebagai salah satu komponen penting dalam proses pendidikan. Pola atau metode dituntut untuk selalu dinamis sesuai

54 | FaLASIFA, Vol. 10 Nomor 1 Maret 2019 
dengan dinamika dan perkembangan peradaban manusia. Pola atau metode pendidikan agama dalam Islam pada dasarnya mencontoh pada perilaku Nabi $\mathrm{Mu}$ hammad SAW dalam membina keluarga dan sahabatnya. Karena segala apa yang dilakukan oleh Nabi Muhammad SAW merupakan manifestasi dari kandungan alQuran. Adapun dalam pelaksanaannya, Nabi memberikan kesempatan pada para pengikutnya untuk mengembangkan cara sendiri selama cara tersebut tidak bertentangan dengan prinsip-prinsip pelaksanaan pendidikan yang dilakukan oleh Nabi.

Abdurrahman Al-Nahlawi dalam bukunya Ushulu al-Tarbiyah al-Islamiyah wa Ashalibiha mencoba mengembangkan metode pendidikan Qurani, yang disebut metode pendidikan Qurani ialah salah satu metode pendidikan yang berdasarkan kandungan alQuran dan as-Sunnah. Dalam hal ini, segala bentuk upaya pendidikan didasarkan kepada nilai-nilai yang terdapat dalam al-Quran dan asSunnah. ${ }^{14}$ Allah SWT berfirman, yang artinya; "(Beberapa hari yang ditentukan itu ialah) bulan Ramadan, bulan yang di dalamnya diturunkan (permulaan) al-Quran sebagai petunjuk bagi manusia dan penjelasan-penjelasan mengenai petunjuk itu dan pembeda (antara yang hak dan yang batil)" (Q.S. A-Baqarah : 185). ${ }^{15}$ Ayat diatas mengisyaratkan bahwa al-Quran selain berfungsi sebagai sumber nilai yang harus dikembangkan dalam dunia pendidikan, juga dapat dijadikan sebagai sumber dalam melakukan tindakan pendidikan. Tujuan pendidikan Qurani diarahkan kepada suatu hasil yang bersifat fisik, mental, dan spiritual. Ketiga hal tersebut merupakan satu kesatuan yang utuh yang akan membentuk kepribadian peserta didik. Tujuan yang bersifat fisik yaitu tingkah laku yang tampak secara nyata, berupa tindakan-tindakan pengalaman ibadah ritual. Sedangkan tujuan yang bersifat mental berkaitan dengan tanggung jawab pengembangan intelegensi yang mengantarkan peserta didik kepada kebenaran tertinggi melalui penyajian fakta-fakta yang relevan dan memadai, dimana fakta-fakta itu dapat memberikan kesaksian dan eksistensi Allah SWT. Disamping itu bertujuan untuk mendorong dan mengantarkan peserta didik kepada berfikir logis dan kritis.

Sementara tujuan spiritual berkaitan dengan kualitaskualitas ruhaniah manusia yang mengarah pada perwujudan kualitas kepribadian yang bersifat ruhaniah dan penampakan pengaruhnya pada perilaku yang nyata dalam tingkah laku, akhlak dan moralitas yang mencerminkan kualitas pendidikan. Dalam pelaksanaan pendidikan agama dalam keluarga dapat menggunakan pola atau metode pendidi-

${ }^{14}$ Syahidin, Aplikasi Pendidikan Qurani (Tasikmalaya: Pondok Pesantren Suralaya, 2005), hal. 59.

${ }^{15}$ Departemen Agama RI, Al-Quran dan Terjemahnya (Semarang: Kumudasmoro Grafindo, 1994).

FaLASIFA, Vol. 10 Nomor 1 Maret 2019 | 55 


\section{Nanang Budianto}

kan Qurani. Adapun pendidikan Qurani yang dapat dilakukan dalam pendidikan agama dalam keluarga diantaranya sebagai berikut :

1. Pendidikan Keteladanan Yaitu suatu pola atau metode pendidikan dengan cara memberikan contoh yang baik kepada anak didik, baik dalam ucapan maupun perbuatan. Keteladanan merupakan salah satu metode pendidikan yang diterapkan Rasulullah SAW dan dianggap paling banyak pengaruhnya terhadap keberhasilan menyampaikan misi da'wahnya. Sebagai umat Islam, sudah seharusnya mencontoh perilaku Nabi Muhammad SAW, karena dalam dirinya telah ada keteladanan yang mencerminkan ajaran al-Quran.

Menurut al-Ghazali anak adalah amanat bagi orang tuanya. Hatinya yang suci merupakan permata tak ternilai harganya, masih murni dan belum terbentuk. ${ }^{16}$ Orang tuanya merupakan arsitek atau pengukir kepribadian anaknya. Sebelum mendidik orang lain, sebaiknya orang tua harus mendidik pada dirinya terlebih dahulu. Sebab anak merupakan peniru ulung. Segala informasi yang masuk pada diri anak, baik melalui penglihatan ataupun pendengaran dari orang di sekitarnya, termasuk orang tua akan membentuk karakter anak tersebut. Apalagi anak yang berumur sekitar 3-6 tahun, ia senantiasa melakukan imitasi terhadap orang yang ia kagumi (ayah dan ibunya).

Rasa imitasi dari anak yang begitu besar, sebaiknya membuat orang tua harus ekstra hati-hati dalam bertingkah laku, apalagi di depan anak-anaknya. Sekali orang tua ketahuan berbuat salah di hadapan anak, jangan berharap anak akan menurut apa yang diperintahkan. Oleh karena itu sudah sepantasnya bagi orang tua pemegang amanat, untuk memberikan teladan yang baik kepada putra putrinya dalam kehidupan berkeluarga. Keluarga merupakan sekolah pertama bagi anak. Orang tua terutama ibu merupakan pendidik pertama dan utama bagi anak dalam membentuk pribadinya.

Ibu memengaruhi anak melalui sifatnya yang menghangatkan, menumbuhkan rasa diterima, dan menanamkan rasa aman pada diri anak. Sedangkan ayah memengaruhi anaknya melalui sifatnya yang mengembangkan kepribadian, menanamkan disiplin, memberikan arah dan dorongan serta bimbingan agar anak tambah berani dalam menghadapi kehidupan. ${ }^{17}$

Teladan yang baik dari orang tua kepada anak (sekitar umur 6 tahun) akan berpengaruh besar kepada perkembangan anak di masa mendatang. Sebab kebaikan di waktu kanak-kanak awal menjadi dasar untuk pengembangan di masa de-

${ }^{16}$ Haya Binti Mubarok al-Barik, Mausu'ah al-Mar'atul Muslimah, Terj. Amir Hamzah Fachrudin, "Ensiklopedi Wanita Muslimah" (Jakarta: Darul Falah, 1998), hal. 247.

17 Abdurrahman 'Isawi, Anak dalam Keluarga (Jakarta: Studia Press, 1994), hal. 35.

56 | FaLASIFA, Vol. 10 Nomor 1 Maret 2019 
wasa kelak. Untuk itu lingkungan keluarga harus sebanyak mungkin memberikan keteladanan bagi anak. Dengan keteladanan akan memudahkan anak untuk menirunya. Sebab keteladanan lebih cepat memengaruhi tingkah laku anak. Apa yang dilihatnya akan ia tirukan dan lama kelamaan akan menjadi tradisi bagi anak. Hal ini sesuai firman Allah SWT QS. al-Ahzab (33) : $21^{18}$;

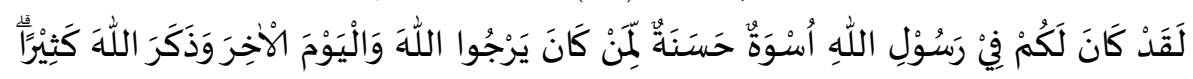

Artinya: "Sesungguhnya telah ada pada (diri) Rasulullah itu suri teladan yang baik bagimu (yaitu) bagi orang yang mengharap (rahmat) Allah dan (kedatangan) bari kiamat dan dia banyak menyebut Allab" (QS. al-Abzab: 21).

Dalam hal keteladanan ini, lebih jauh Abdullah Nashih Ulwan menafsirkan dalam beberapa bentuk, yaitu: a. Keteladanan dalam ibadah. b. Keteladanan bermurah hati. c. Keteladanan kerendahan hati. d. Keteladanan kesantunan. e. Keteladanan keberanian. f. Keteladanan memegang akidah. ${ }^{19}$

Oleh karena objeknya anak (kanak-kanak), tentunya bagi orang tua dalam memberikan teladan harus sesuai dengan perkembangannya sehingga anak mudah mencerna apa yang disampaikan oleh bapak ibunya. Sebagai contoh agar anak membiasakan diri dengan ucapan "salam", maka senantiasa orang tua harus memberikan ajaran tersebut setiap hari, yaitu mengucap salam ketika hendak pergi dan pulang ke rumah. Yang penting bagi orang tua tampil dihadapan anak sesuai dengan ajaran-ajaran Islam, niscaya semua itu akan ditirunya.

2. Pendidikan dengan adat kebiasaan

Setiap manusia yang dilahirkan membawa potensi, salah satunya berupa potensi beragama. Potensi beragama ini dapat terbentuk pada diri anak (manusia) melalui 2 faktor, yaitu: faktor pendidikan Islam yang utama dan faktor pendidikan lingkungan yang baik. Faktor pendidikan Islam yang bertanggung jawab penuh adalah bapak ibunya. Ia merupakan pembentuk karakter anak. Hal ini sesuai dengan sabda Rasul SAW; ${ }^{20}$

عن ابى هريرة رضى الله عنه قال: قال النبي صل الله عليه وسلم كل مولود يولد على الفطرة فأبواه

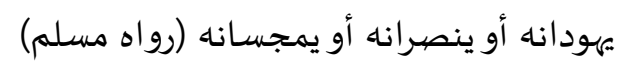

${ }^{18}$ Departemen Agama RI, Al-Quran dan Terjemahnya (Semarang: Kumudasmoro Grafindo, 1994).

${ }_{19}$ Abdullah Nashih Ulwan, Tarbiyatul Aulad fil-Islam, Terj. Khalilullah Ahmas Masjkur Hakim, "Pemeliharaan Kesehatan Jiwa Anak" (Bandung: Remaja Rosda Karya, 1992), hal. 5.

${ }^{20}$ Imam Muslim, Sahih Muslim, Juz IV (Lebanon: Dar al-Kutbi al-Ilmiah, tt), 2047.

FALASIFA, Vol. 10 Nomor 1 Maret 2019 | 57 
Nanang Budianto

Artinya: "Dari Abi Hurairah ra., telah bersabda Rasulullah SAW.: tidak ada anak yang dilabirkan kecuali dalam keadaan fitrah. Maka kedua orang tuanyalah yang akan menjadikannya sebagai orang Yahudi, Nasrani, atau Majusi” (HR. Muslim).

Setelah anak diberikan masalah pengajaran agama sebagai sarana teoretis dari orang tuanya, maka faktor lingkungan harus menunjang terhadap pengajaran tersebut, yakni orang tua senantiasa memberikan aplikasi pembiasaan ajaran agama dalam lingkungan keluarganya. Sebab pembiasaan merupakan upaya praktis dan pembentukan (pembinaan) dan persiapan. ${ }^{21}$

Pada umur kanak-kanak kecenderungan anak adalah meniru apa yang dilakukan oleh orang-orang di sekitarnya, baik saudara famili terdekatnya ataupun bapak ibunya. Oleh karena itu patut menjadi perhatian semua pihak, terutama orang tuanya selaku figur yang terbaik di mata anaknya. Jika orang tua menginginkan putra putrinya tumbuh dengan menyandang kebiasaan-kebiasaan yang baik dan akhlak terpuji serta kepribadian yang sesuai ajaran Islam, maka orang tua harus mendidiknya sedini mungkin dengan moral yang baik. Karena tiada yang lebih utama dari pemberian orang tua kecuali budi pekerti yang baik. Hal ini sesuai dengan sabda Rasul SAW yang diriwayatkan al-Tirmidzi dari Ayyub bin $\mathrm{Mu}-$ $\mathrm{sa}^{22}$

حدثنا أيوب بن موسى عن أبيه عن جده أن رسول الله صلى الله عليه وسلم قالما نحل والد ولدا

$$
\text { من نحل أفضل من أدب حسن (رواه الترمذى) }
$$

Artinya: "Diceritakan dari Ayyub bin Musa dari ayahnya dari kakeknya, bahwa Rasulullah SAW bersabda: Tidak ada pemberian yang lebih utama dari seorang ayah $k e-$ pada anaknya kecuali budi pekerti yang baik" (H.R At-Tirmidzi).

Apabila anak dalam lahan yang baik (keluarganya) memeroleh bimbingan, arahan, dan adanya saling menyayangi antar anggota keluarga, niscaya lambat laun anak akan terpengaruh informasi yang ia lihat dan ia dengar dari semua perilaku orang- orang di sekitarnya. Dan pengawasan dari orang tua sangat diperlukan sebagai kontrol atas kekeliruan dari perilaku anak yang tak sesuai dengan ajaran Islam.

3. Pendidikan dengan Nasihat

Pemberi nasihat seharusnya orang yang berwibawa di mata anak. Pemberi nasihat dalam keluarga tentunya orang tuanya sendiri selaku pendidik bagi anak. Anak akan mendengarkan nasihat tersebut, apabila pemberi nasihat juga bisa

\footnotetext{
${ }^{21}$ http://Mustafidinahmad.wordpress.com.

${ }^{22}$ Sunan at-Tirmidzi, al-Jami'us Sabih, Juz IV (Lebanon: Dar al-Kutbi, tt), hal. 298.
}

58 | FaLASIFA, Vol. 10 Nomor 1 Maret 2019 
memberi keteladanan. Sebab nasihat saja tidak cukup bila tidak diikuti dengan keteladanan yang baik. Anak tidak akan melaksanakan nasihat tersebut apabila didapatinya pemberi nasihat tersebut juga tidak melaksanakannya. Anak tidak butuh segi teoretis saja, tapi segi praktislah yang akan mampu memberikan pengaruh bagi diri anak. Nasihat yang berpengaruh, membuka jalannya ke dalam jiwa secara langsung melalui perasaan. Setiap manusia (anak) selalu membutuhkan nasihat, sebab dalam jiwa terdapat pembawaan yang biasanya tidak tetap, dan oleh karena itu kata- kata atau nasihat harus diulang-ulang. ${ }^{23}$ Nasihat akan berhasil atau memengaruhi jiwa anak, tatkala orang tua mampu memberikan keadaan yang baik. Hal ini sesuai dengan firman Allah SWT dalam QS. al-Baqarah: $44{ }^{24}$

Artinya: "Mengapa kamu suruh orang lain (mengerjakan) kabaktian, sedang kamu melupakan diri (kewajiban) mu sendiri, Padabal kamu membaca al-Kitab (Taurat)? Maka tidakkah kamu berpikir?” (Q.S. al-Baqarah: 44).

Agar harapan orang tua terpenuhi yakni anak mengikuti apa-apa yang telah diperintahkan dan yang telah diajarkannya, tentu disamping memberikan nasihat yang baik juga ditunjang dengan teladan yang baik pula. Karena pembawaan anak mudah terpengaruh oleh kata-kata yang didengarnya dan juga tingkah laku yang sering dilihatnya dalam kehidupan sehari-hari dari pagi hari sampai sore hari.

Nasihat juga harus diberikan sesering mungkin kepada anak-anak masa sekolah dasar, sebab anak sudah bersosial dengan teman sebayanya. Agar apa-apa yang telah diberikan dalam keluarganya tidak mudah luntur atau tepengaruh dengan lingkungan barunya.

Menurut Ulwan, dalam penyajian atau memberikan nasihat itu ada pembagiannya, yaitu :

a. Menyeru untuk memberikan kepuasan dengan kelembutan atau penolakan. Sebagai contohnya adalah seruan Luqman kepada anak-anaknya, agar tidak mempersekutukan Allah SWT. Q.S. Luqman (31) ayat 13, artinya;

Artinya: "Dan (ingatlah) ketika Luqman berkata kepada anaknya, di waktu ia memberi pelajaran kepadanya: "Hai anakku, janganlah kamu mempersekutukan Allah, sesunggubnya mempersekutukan (Allah) adalah benar-benar kezaliman yang besar" (Q.S Luqman: 13).

b. Metode cerita dengan disertai tamsil ibarat dan nasihat

Metode ini mempunyai pengaruh terhadap jiwa dan akal. Biasanya anak itu

${ }^{23}$ Muhammad Quthb, Sistem Pendidikan Islam, Terj. Salman Harun (Bandung: Ma’arif, 1993), hal. 334.

${ }^{24}$ Departemen Agama RI, Al-Qwran dan Terjemahnya (Semarang: Kumudasmoro Grafindo, 1994).

FaLASIFA, Vol. 10 Nomor 1 Maret 2019 | 59 
Nanang Budianto

menyenangi tentang cerita-cerita. Untuk itu orang tua sebisa mungkin untuk memberikan masalah cerita yang berkaitan dengan keteladanan yang baik yang dapat menyentuh perasaannya. Sebagaimana firman-Nya dalam QS. al-A` raf $^{25}$ (7): 176;

Artinya: "... Maka ceritakanlah (kepada mereka) kisah-kisah itu agar mereka berpikir.”

c. Pengarahan melalui wasiat

Orang tua yang bertanggung jawab tentunya akan berusaha menjaga amanatNya dengan memberikan yang terbaik buat anak demi masa depannya dan demi keselamatannya.

4. Pendidikan dengan Perhatian

Orang tua berkewajiban untuk memenuhi kebutuhan- kebutuhan anaknya, baik kebutuhan jasmani ataupun kebutuhan yang berbentuk ruhani. Diantara kebutuhan anak yang bersifat ruhani adalah anak ingin diperhatikan dalam perkembangan dan pertumbuhannya. Pendidikan dengan perhatian adalah mencurahkan, memperhatikan dan senantiasa mengikuti perkembangan anak dalam pembinaan akidah dan moral, persiapan spiritual dan sosial, disamping selalu bertanya tentang situasi pendidikan jasmani dan daya hasil ilmiahnya. ${ }^{26}$

Orang tua yang bijaksana tentunya mengetahui perkembangan anaknya. Ibu adalah pembentuk pribadi putra putrinya lebih besar prosentasenya dibanding seorang ayah. Tiap hari waktu Ibu banyak bersama dengan anak, sehingga wajar bila kecenderungan anak lebih dekat dengan para ibunya. Untuk itu ibu diharapkan mampu berkiprah dalam mempersiapkan pertumbuhan dan perkembangan putra-putrinya. Bunda Darosy menjelaskan bahwa ibu adalah pendidik utama bagi anak-anaknya. Ibu sebagai pencipta, ibu sebagai pemelihara suasana. Peran ini tidak bisa digantikan oleh siapapun. Prinsip-prinsip dasar kehidupan, seperti agama, nilai kebenaran, nilai kebaikan dan keburukan, perilaku-perilaku dasar pada pola pendidikan anak dalam keluarga. Sehingga seorang ibu harus berusaha menjadi sahabat anak-anaknya sebagai jembatan emas menyatukan anak dan orang tua dalam hubungan yang akrab dan mesra. ${ }^{27}$

Orang tua yang baik senantiasa akan mengoreksi perilaku anaknya yang tidak baik dengan perasaan kasih sayangnya, sesuai dengan perkembangan usia anaknya. Sebab pengasuhan yang baik akan menanamkan rasa optimisme, keper-

\footnotetext{
${ }^{25}$ Departemen Agama RI, Al-Qur'an dan Terjemahnya (Semarang: Kumudasmoro Grafindo, 1994).

${ }^{26}$ Abdullah Nashih Ulwan, Tarbiyatul Aulad fil Islam.. hal. 123.

${ }^{27}$ Darosy Endah Hyoscyamina, Cahaya Cinta Ibunda (Semarang: DNA Creative House, 2013), hal. 136.
}

60 | FaLASIFA, Vol. 10 Nomor 1 Maret 2019 
cayaan, dan harapan anak dalam hidupnya. ${ }^{28}$ Dalam memberi perhatian ini, hendaknya orang tua bersikap selayak mungkin, tidak terlalu berlebihan dan juga tidak terlalu kurang. Namun perhatian orang tua disesuaikan dengan perkembangan dan pertumbuhan anak.

Apabila orang tua mampu bersikap penuh kasih sayang dengan memberikan perhatian yang cukup, niscaya anak-anak akan menerima pendidikan dari orang tuanya dengan penuh perhatian juga. Namun pangkal dari seluruh perhatian yang utama adalah perhatian dalam akidah

5. Pendidikan dengan memberikan hukuman

Hukuman diberikan, apabila metode-metode yang lain sudah tidak dapat merubah tingkah laku anak, atau dengan kata lain cara hukuman merupakan jalan terakhir yang ditempuh oleh pendidik, apabila ada perilaku anak yang tidak sesuai dengan ajaran Islam. Sebab hukuman merupakan tindakan tegas untuk mengembalikan persoalan di tempat yang benar. ${ }^{29}$ Hukuman sesungguhnya tidaklah mutlak diberikan. Karena ada orang dengan teladan dan nasihat saja sudah cukup, tidak memerlukan hukuman. Tetapi pribadi manusia tidak sama seluruhnya. Seorang pendidik haruslah mengenal siapa dan bagaimana watak anak didiknya, karena terkadang sikap negatif yang dimunculkan anak adalah bentuk dari proses kecerdasannya. Sehingga harus hati-hati dalam menyikapinya agar tidak terjadi trauma pada anak yang dapat mematahkan daya kreatif dan inovasinya.

Sebenarnya tidak ada pendidik yang tidak sayang kepada siswanya. Demikian juga tidak ada orang tua yang merasa senang melihat penderitaan anaknya. Dengan memberikan hukuman, orang tua sebenarnya merasa kasihan terhadap anaknya yang tidak mau melaksanakan ajaran Islam. Karena salah satu fungsi dari hukuman adalah mendidik.26 Sebelum anak mengerti peraturan, ia dapat belajar bahwa tindakan tertentu benar apabila tidak menerima hukuman dan tindakan lainnya salah apabila mendapatkan suatu hukuman.

Dalam memberikan hukuman ini diharapkan orang tua melihat ruang waktu dan tempatnya. Diantara metode memberikan hukuman kepada anak adalah: a. Menghukum anak dengan lemah lembut dan kasih sayang. b. Menjaga tabiat anak yang salah. c. Hukuman diberikan sebagai upaya perbaikan terhadap diri anak,

${ }^{28}$ Muhammad Ali al-Hasyimi, The Ideal Muslimah the True Islamic Personality of The Muslim Woman as Defined in The Qur'an and Sunnah, Terj. Fungky Kusnaedi Timur, "Muslimah Ideal Pribadi Islami dalam al-Qur'an dan asSunnah" (Yogyakarta: Mitra Pustaka, 2000), hal. 262.

${ }^{29}$ Muhammad 'Ali Quthb, Auladuna fi-Dlaw-it Tarbiyyatil Islamiyah, Terj. Bahrun Abu Bakar Ihsan, "Sang Anak dalam Nanngan Pendidikan Islam" (Bandung: Diponegoro, 1993), hal. 341. 
Nanang Budianto

dengan tahapan yang paling akhir dari metode-metode yang lain.

Memberi hukuman pada anak, seharusnya para orang tua sebisa mungkin menahan emosi untuk tidak memberi hukuman berbentuk badaniah. Kalau hukuman yang berbentuk psikologis sudah mampu merubah sikap anak, tentunya tidak dibutuhkan lagi hukuman yang menyakitkan anak tersebut. Menurut Nashih Ulwan, hukuman bentuknya ada dua, yakni hukuman psikologis dan hukuman biologis. Bentuk hukuman yang bersifat psikologis adalah: a. Menunjukkan kesalahan dengan pengarahan. b. Menunjukkan kesalahan dengan memberikan isyarat. c. Menunjukkan kesalahan dengan kecaman.

Hukuman bentuk psikologis ini diberikan kepada anak dibawah umur 10 tahun. Apabila hukuman psikologis tidak mampu merubah perilaku anak, maka hukuman biologislah yang dijatuhkan tatkala anak sampai umur 10 tahun tidak ada perubahan pada sikapnya. Hal ini dilakukan supaya anak jera dan tidak meneruskan perilakunya yang buruk. Sesuai sabda Rasul SAW yang diriwayatkan Abu Daud dari Mukmal bin Hisyam.

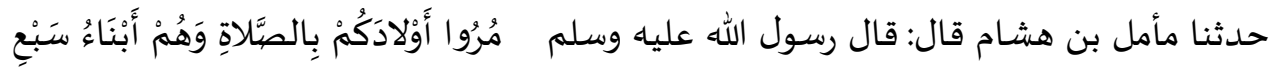

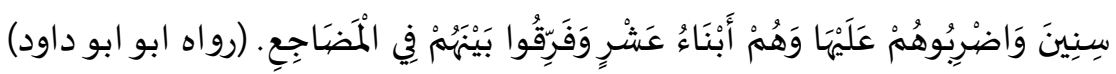

Artinya: "Surublah anak kalian mengerjakan shalat, sedang mereka berumur tujuh tahun, dan pukulilah mereka itu karena shalat ini, sedang mereka berumur sepuluh tahun, dan pisabkanlah tempat tidur mereka” (HR. Abu Daud).

\section{KESIMPULAN}

Dari pemaparan mengenai pendidikan anak dalam keluarga berperspektif Islam, dapat ditarik beberapa kesimpulan bahwa Pendidikan dalam keluarga yang berperspektif Islam adalah pendidikan yang didasarkan pada tuntunan agama Islam yang diterapkan dalam keluarga yang dimaksudkan untuk membentuk anak agar menjadi manusia yang beriman dan bertaqwa pada Tuhan Yang Maha Esa, serta berakhlak mulia yang mencakup etika, moral, budi pekerti, spiritual atau pemahaman dan pengalaman nilai-nilai keagamaan dalam kehidupan sehari-hari. Pendidikan agama Islam untuk anak-anak harus dilakukan semenjak janin masih dalam kandungan. Pendidikan agama Islam ini dilakukan dengan cara mengadakan selamatan dan pembacaan alQuran. Ketika bayi sudah lahir, hendaknya dilanjutkan dengan pendidikan agama Islam berikutnya, yaitu memperdengarkan adzan dan iqamah, memberi nama yang baik, walimatul aqiqoh dan walimatul khitan. Pola pendidikan Islam yang dapat dipraktikkan oleh orang tua adalah pola keteladaan, adat kebiasaan, nasihat, perhatian dan pola ganjaran dan hukuman. Polapola pendidikan yang dipraktikkan tersebut tidak berdiri sendiri, tetapi saling

62 | FaLASIFA, Vol. 10 Nomor 1 Maret 2019 
mendukung dan terkait satu dengan lainnya. Pola-pola tersebut juga dipraktikkan sesuai dengan situasi dan kondisi yang ada.

\section{DAFTAR PUSTAKA}

Al-Abrasyi, M. 'Athiyah, 1970, Dasar-dasar Pokok Pendidikan Islam. Terj. Bustami A. Gani dan Djohar Bahry (Jakarta: Bulan Bintang).

At-Tirmidzi, Sunan, tt., al-Jami'us Sabih, Juz IV (Lebanon: Dar al-Kutbi).

Al-Hasyimi, Muhammad Ali, 2000, The Ideal Muslimah the True Islamic Personality of The Muslim Woman as Defined in The Qur'an and sunnah, Terj. Fungky Kusnaedi Timur, "Muslimah Ideal pribadi Islami dalam al-Qur'an dan asSunnah” (Yogyakarta: Mitra Pustaka).

Al-Barik, Haya Binti Mubarok, 1998, Mausu'ah al-Mar'atul Muslimah, Terj. Amir Hamzah Fachrudin, "Ensiklopedi Wanita Muslimah” (Jakarta: Darul Falah).

Aly, Hery Noer \& Munzier, 2003, Watak Pendidikan Islam (Jakarta: Friska Agung Insani).

Arief, Armai, 2002, Pengantar Ilmu dan Metodologi Pendidikan Islam (Jakarta: Ciputat Pers).

Departemen Agama RI, 1994, Al-Qur'an dan Terjemahnya (Semarang: Kumudasmoro Grafindo).

http://hadith.al-Islam.com

http://muslim.or.id

http://Mustafidinahmad.wordpress.com

Hurlock, Elizabeth B., 1999, Perkembangan Anak, Terj. Med. Meitasari Tjandrasa (Jakarta: Erlangga).

Hyoscyamina, Darosy Endah, 2013, Cahaya Cinta Ibunda (Semarang: DNA Creative House).

'Isawi, Abdurrahman, 1994, Anak dalam Keluarga (Jakarta: Studia Press).

Langgulung, Hasan, 2003, Asas-Asas Pendidikan Islam (Jakarta: Pustaka al-Husna Baru).

Muslim, Imam, tt., Sahih Muslim, Juz IV (Lebanon: Dar al-Kutbi alIlmiah).

Mahmud, Ali Abdul Halim, 2000, Pendidikan Rubani (Jakarta: Gema Insani)

Quthb, Muhammad 'Ali, 1993, Auladuna fi-Dlaw-it Tarbiyyatil Islamiyah, Terj. Bahrun Abu Bakar Ihsan, "Sang Anak dalam Naungan Pendidikan Islam" (Bandung: Diponegoro)

Quthb, Muhammad, 1993, Sistem Pendidikan Islam, Terj. Salman Harun (Bandung: Ma'arif). 
Nanang Budianto

Suwarno, 1992, Pengantar Umum Pendidikan (Jakarta: Rineka Cipta)

Syahidin, 2005, Aplikasi Pendidikan Qur'ani (Tasikmalaya: Pondok Pesantren Suralaya).

Tafsir, Ahmad, 2001, Ilmu Pendidikan dalam Perspektif Islam (Bandung: Remaja Rosda Karya).

Ulwan, Abdullah Nashih, 1992, Tarbiyatul Aulad fil Islam, Terj. Khalilullah Ahmas Masjkur Hakim, "Pemeliharaan Kesehatan Jiwa Anak" (Bandung: Remaja Rosda Karya).

Zuhairini, dkk., 1981, Metodik Khusus Pendidikan Agama (Surabaya : Usaha Nasional).

64 | FaLASIFA, Vol. 10 Nomor 1 Maret 2019 